\title{
ULTRAMARINE, LAZURITE AND SODALITE STUDIED BY POSITRON ANNIHILATION AND EPR METHODS
}

\author{
A. Baranowski, M. Dębowska, K. Jerie \\ Institute of Experimental Physics, Wrocław University \\ Maxa Borna 9, 50-204 Wrocław, Poland
}

\section{A. JEZIERSKI}

Institute of Chẹmistry, Wroclaw University, Joliot Curie 14, 50-383 Wrocław, Poland

AND M. SACHANBIŃSKI

Institute of Geological Sciences, Wrocław University

Maxa Borna 9, 50-204 Wrocław, Poland

Studies of positron annihilation accompanied by EPR technique were undertaken for sodalite and lazurite and their synthetic counterparts (synthetic sodalite and ultramarines). Results of measurements performed by two techniques of positron annihilation spectroscopy (angular correlation of annihilation radiation, ACAR, and positron annihilation lifetime) revealed the undoubted influence of free radicals on positron annihilation mechanism but both inhibition of positronium formation by them and the effect of filling cages ought to be taken in to account. The distinct differences between ACAR curves for sodalites, lazurites and ultramarines probably reflect the presence of different radicals in their cages and chemical heterogeneity as well as the disorder in $\mathrm{Al}$, Si-site ordering in case of ultramarines. Comparison of the results of ACAR measurements with the ones of the EPR studies indicates that there is correspondence between them. Similarly to three families of the ACAR curves, different types of EPR lines were obtained for three groups of samples; sodalites, lazurites and ultramarines. It is possible that the annihilation of positrons takes place mainly with unpaired electrons recorded by the EPR technique.

PACS numbers: $61.90 .+\mathrm{d}, 71.60 .+\mathrm{z}, 76.30 .-\mathrm{v}, 78.70 .-\mathrm{g}$ 


\section{Introduction}

Methods of positron annihilation spectroscopy (PAS) are very useful in studies of minerals (cf. the comprehensive paper by Sachanbiński et al. [1]). In particular, minerals of ionic character of chemical bonding, native elements and natural alloys of metals have been successfully studied by PAS. Methods of PAS have been most frequently used to study electronic structure, structural defects $[2,3]$ and pores in minerals $[4,5]$ as well as such a phenomenon as their dehydration [6]. Very often PAS results obtained for natural substance and its synthetic counterpart have been compared [7]. In this case the synthetic material has often been assumed as a model.

Pores, conglomerates of vacancies, empty spaces and free volume in the substance usually promote formation of positronium and are sites of its localization if energetic conditions allow it. Trapping of the positronium in cages of certain zcolites has been suggested $[8,9]$ and the influence of such phenomena as absorption of different gases [10], water [11] and impregnation of zeolites [12] on positron annihilation parameters has been emphasized.

EPR is a spectroscopic technique using absorption of microwaves by paramagnetic substance placed in an external magnetic field. The beginning of the use of this technique in studies of minerals dates to the fifties of the 20th century. At the turn of the sixties first monograph papers were published [13-16] on it. At present, EPR is a standard physical technique to study minerals and rocks. It has advantage of being nondestructive and not requiring great amount of studied material. The most interesting is the possibility of combining results of EPR studies with age, conditions of formation and geological history of minerals and rocks [17].

The aim of our investigations was to study positron annihilation in samples of different minerals with the framework composed of the same building unit and in their synthetic counterparts. The interesting question of the influence of free radicals, present in majority of samples, on o-Ps characteristics seemed to be worthy to be studied thus the PAS studies were accompanied by the EPR ones.

\section{Experimental}

\subsection{Samples}

Five samples of minerals (two sodalites and three lazurites) and eight synthetic samples (sodalite and ultramarines) were studied by us with the use of both PAS and EPR technique. All samples were polycrystalline. Their symbols and origin are given in Table. Samples of minerals came from the Mineralogical Museum of Wrocław University, while the synthetic samples were kindly supplied by Prof. Y. Ito (No. 1), Prof. A. Więckowski (Nos. 5, 6, 9, 11, 13) and by Dr. A. Stelmaszczyk (Nos. 10, 12).

Sodalite is a zeolite and its structure contains only one kind of a framework cavity.

Zeolites are framework silicates built from corner-sharing $\mathrm{SiO}_{4}^{4-}$ and $\mathrm{AlO}_{4}^{5-}$ tetrahedra and containing regular systems of intracrystalline cavities and channels of molecular dimensions. The negative charge of the framework, equal to the 
Characteristics of samples.

TABLE

\begin{tabular}{|c|c|c|}
\hline $\begin{array}{l}\text { No. of } \\
\text { the sample }\end{array}$ & Name of the sample, its symbol and origin & $\begin{array}{l}\text { Concentration of } \\
\text { free radical from } \\
\text { EPR measurements } \\
{\left[10^{18} \text { spin } / \mathrm{g}\right]}\end{array}$ \\
\hline 1 & $\begin{array}{c}\text { synthetic sodalite } \\
\text { (Exxon Nuclear Idaho Co.) }\end{array}$ & 0 \\
\hline 2 & $\begin{array}{c}\text { natural sodalite } \\
\text { (blue sodalite from Columbia) }\end{array}$ & 0.87 \\
\hline 3 & $\begin{array}{c}\text { natural sodalite } \\
\text { (blue sodalite from Capetown area, South Africa) }\end{array}$ & 1.6 \\
\hline 4 & $\begin{array}{c}\text { lazurite } \\
\text { (from the Malobystrinskoye deposit on the southern coast } \\
\text { of Baikal Lake) }\end{array}$ & 3.02 \\
\hline 5 & $\begin{array}{c}\text { ultramarine red } \\
\text { (URo, R804, Reckitt's Colours Co., Darmstadt) }\end{array}$ & $\overline{19.4}$ \\
\hline 6 & $\begin{array}{c}\text { ultramarine green } \\
\text { (UGR, G601, Reckitt's Colours) }\end{array}$ & $\overline{20.2}$ \\
\hline 7 & $\begin{array}{c}\text { lazurite } \\
\text { (lapis-lazuli from Pamir Mts.) }\end{array}$ & 42.5 \\
\hline 8 & $\begin{array}{c}\text { lazurite } \\
\text { (lapis-lazuli from Afghanistan) }\end{array}$ & 53.1 \\
\hline 9 & $\begin{array}{c}\text { ultramarine violet } \\
\text { (UVI, V705, Reckitt's Colours) } \\
\end{array}$ & 62.5 \\
\hline 10 & $\begin{array}{c}\text { ultramarine } \\
\text { (DTO II, Zaklady Farb i Lakierów Polifarb, Kalisz, Poland) }\end{array}$ & 90.4 \\
\hline 11 & $\begin{array}{c}\text { ultramarine blue } \\
\text { (UBl, V/8060; Reckitt's Colours) }\end{array}$ & 134 \\
\hline 12 & $\begin{array}{c}\text { ultramarine } \\
\text { (DTO I, Zaklady Farb i Lakierów Polifarb, Kalisz, Poland) }\end{array}$ & 141 \\
\hline 13 & $\begin{array}{c}\text { ultramarine blue } \\
\text { (UBI, IV/307, Reckitt's Colours) }\end{array}$ & 204 \\
\hline
\end{tabular}

number of constituent aluminium atoms, is balanced by exchangeable cations, $\mathrm{M}^{n+}$, typically sodium, located in the channels which normally also contain water.

The general oxide formula of a zeolite is $\mathrm{M}_{x / n}\left(\mathrm{AlO}_{2}\right)_{x}\left(\mathrm{SiO}_{2}\right)_{y} \cdot m \mathrm{H}_{2} \mathrm{O}$ with $y>x$. This means that, since each silicate and aluminium tetrahedron is linked via oxygen bridges to four other tetrahedra, aluminate tetrahedra cannot be neighbours in a zeolitic framework, i.e. Al-O-Al linkages are forbidden (Loewenstein's rule).

A line drawing of the sodalite structure is given in Fig. 1. The truncated octahedral sodalite cage (14-hedron) formed by joining $\mathrm{Si}$ and $\mathrm{Al}$ atoms is shown (Fig. 1a), together with a representation of the stacking of cages in the complete crystal (Fig. 1b). Access to these 14-hedral voids is through 6-ring oxygen windows of the free diameter equal to $0.22 \mathrm{~nm}$ [19]. Small atoms such as $\mathrm{Na}$ and small molecules such as water can pass through by, ions such as $\mathrm{Cl}^{-}$are firmly trapped inside. The free diameter of a 14-hedron is about $0.66 \mathrm{~nm}$ while the volume of the cage is equal to $0.157 \mathrm{~nm}^{3}$. The sodalite cages are fairly large, thus up to four tetrahedrally arranged cations can be placed within them together with one monomeric anion at the centre of the cage. Natural chlorine-bearing sodalite crystallizes in the cubic system, $a_{0}=0.887 \mathrm{~nm}$, space group $P 43 n$, with a unit cell composition $\mathrm{Na}_{8}\left(\mathrm{Al}_{6} \mathrm{Si}_{6} \mathrm{O}_{24}\right) \mathrm{Cl}_{2}$. The eight sodium ions are structurally equivalent, and placed 

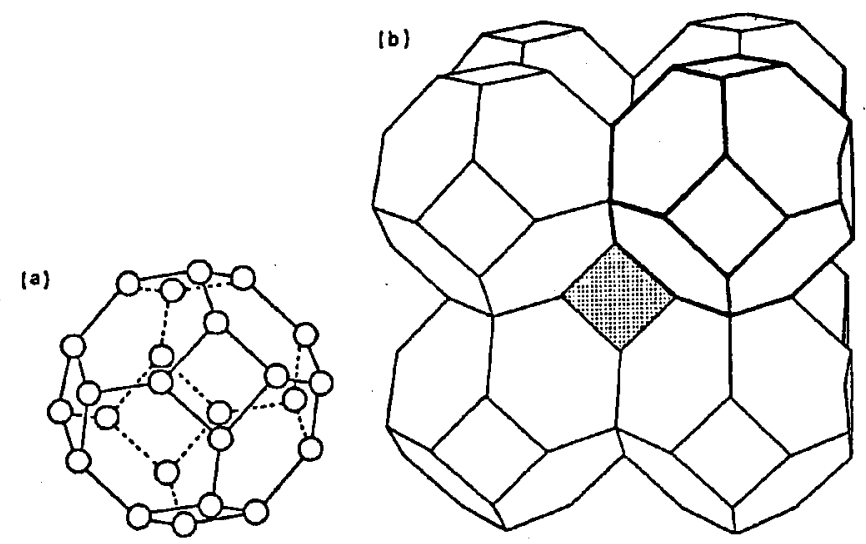

Fig. 1. Idealized drawing of the sodalite structure. (a) Truncated octahedral sodalite cage (14-hedron) formed by joining $\mathrm{Si}$ and $\mathrm{Al}$ atoms.

in certain distance from the plane of the six ring tetrahedral atoms. The distance depends on the extent of hydration of the samples. The chloride ions are situated at the centres of the truncated octahedra with the $\mathrm{Na}-\mathrm{Cl}$ distances of $0.273 \mathrm{~nm}$. It was found that in practice natural sodalite does not adsorb water [19]. X-ray diffraction of the sample No. 2 studied by us allowed to identify sodalite and diopside in it.

Synthetic sodalite: The composition of its unit cell of two cages (14-hedra) is given by the formula $6\left(\mathrm{NaAlSiO}_{4}\right)$. Each unit cell can accommodate at most eight water molecules [18].

Lazurite: The theoretical chemical formula of the unit cell of lazurite is

$(\mathrm{Na}, \mathrm{Ca})_{8}\left[\left(\mathrm{SO}_{4}, \mathrm{~S}, \mathrm{Cl}_{2}\right)\left(\mathrm{AlSiO}_{4}\right)_{6}\right]$.

It is a member of the sodalite group and the same framework as in case of sodalite is present in it. It is known from the single crystal diffraction that lazurite is cubic, space group $P 43 n$ with $a=0.91 \mathrm{~nm}$. Its framework is fully ordered and consists of alternating $\mathrm{SiO}_{4}^{4-}$ and $\mathrm{AlO}_{4}^{5-}$ tetrahedra. The ions $\mathrm{SO}_{4}^{2-}$ and $\mathrm{S}^{2-}$ are often present in place of chlorine. It occurs very rarely as small blue crystals and more commonly as massive aggregates composed of blue lazurite dispersed in a white matrix. The massive variety is called lapis lazuli and used as a highly prized gem. Samples Nos. 4, 7 and 8 were granular aggregates of dark blue lazurite. Small grains of the mineral were dispersed in a light matrix. X-ray diffraction and microscopic observations revealed that the blue components of the samples included lazurite, nosean and pyroxenes and the light minerals of the matrix were pyroxenes and micas. This composition is typical of lapis lazuli.

Ultramarine is the synthetic equivalent of the natural aluminosilicate, lazurite. The name is given to a family of closely related pigments. They are products of industrial furnacing of a mixture of the kaolin, sulphur, sodium carbonate and minor ingredients, especially coal-containing reducing agent. The formed diamagnetic $S^{2-}$ ions are subsequently oxidized to free radicals polymeric $S_{n}$ forms. The basic ingredients and recipe for production are well known and detailed in patents [20]. 
The chemistry and structure of the finished product have also been studied [21]. For the composition of the cubo-octahedral unit of the aluminosilicate structure in different ultramarines including sulphur species of the $S_{x}$ type, the formula $\mathrm{Na}_{6-x} \mathrm{Al}_{6-x-k} \mathrm{Si}_{x+k} \mathrm{O}_{12} \mathrm{~S}_{x}^{k-}$ has been proposed that describes well the experimentally observed compositions of artificial coloured ultramarines [22]. Ultramarine, unlike zeolites displays a random (non-Loewenstein) occupancy of Al, Si-sites [23]. A characteristic feature of ultramarine pigments is that their cavities are occupied, at least partly, by more than two sulphur atoms and the number of cations per cage is smaller than four. Jaeger [24] identified the main structural components of ultramarine: the aluminosilicate (sodalite) cage, the colour group inside the cage and exchangeable cations. The structure of the standard ultramarine is given in Fig. 2.

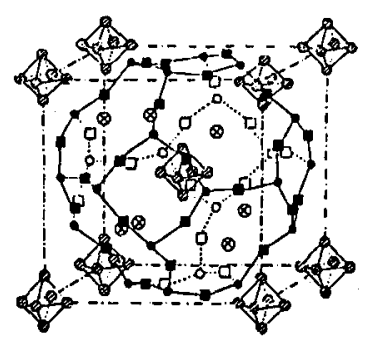

Fig. 2. Schematic drawing of the basic structure of standard ultramarine, showing the available sites for sulphur and sodium: $\square=$ oxygen, $0=$ silicon or aluminium, $\mathrm{O}=$ sodium, $\mathrm{O}=$ sulphur [23].

The real contents of studied ultramarines coming from Reckitt's Colours Co. were given in [25] and correspond to the following formulae:

UGR G $601\left[\begin{array}{lllllll}\mathrm{Si}_{6.05} & \mathrm{Al}_{5.95} & \mathrm{O}_{24}\end{array} \mathrm{Na}_{6.75} \mathrm{~K}_{0.09} \mathrm{~S}_{3.67}\right.$,

UBl IV/307 [ $\left[\begin{array}{llll}\mathrm{Si}_{7.00} & \mathrm{Al}_{5.00} & \mathrm{O}_{24}\end{array}\right] \mathrm{Na}_{5.95} \mathrm{~K}_{0.12} \mathrm{~S}_{3.39}$,

UBI V/8060 [ $\left[\begin{array}{llll}\mathrm{Si}_{6.32} & \mathrm{Al}_{5.67} & \mathrm{O}_{24}\end{array}\right] \mathrm{Na}_{6.37} \mathrm{~K}_{0.10} \mathrm{~S}_{2.66}$,

UVI V $705\left[\begin{array}{llll}\mathrm{Si}_{7.09} & \mathrm{Al}_{4.91} & \mathrm{O}_{24}\end{array}\right] \mathrm{Na}_{5.11} \mathrm{~K}_{0.05} \mathrm{~S}_{3.34}$,

URo R $804\left[\begin{array}{llll}\mathrm{Si}_{7.26} & \mathrm{Al}_{4.74} & \mathrm{O}_{24}\end{array}\right] \mathrm{Na}_{3.73} \mathrm{~K}_{0.03}\left(\mathrm{NH}_{4}\right)_{0.10} \mathrm{~S}_{3.33}$.

A possible excess of oxygen atoms over the number of 24 which form the Si-O-Al framework of the unit cell has to be attributed (a) to a partial oxidation of the sulphidic $\mathrm{S}$ (mainly to sulphur dioxide and to sulphate) which increases within the series UGR < UBl < UVI < URo, and (b) to the water content. Ultramarine is hydrophilic and at most 1.6 water molecules can be absorbed in one sodalite cage [25] that cannot be removed by simple drying.

The ultramarine pigments differ not so much in their sulphur content as in their content of alkali ions which decreases in the order UGR > UBl > UVI > URo. It is remarkable that URo contains altogether fewer sodium, potassium and ammonium ions than aluminium atoms so it is to be supposed that part of oxygen bridges of the ultramarine URo framework is replaced by $\mathrm{OH}$ bridges. Very probably this is also the case in other ultramarine varieties. The decrease in the alkali metal content results in the increase in the space within the cages. 
The ultramarines manufactured by Zakłady Farb i Lakierów in Kalisz (samples Nos. 10 and 12) conform to the Polish standard PN-70/C-81022 and contain about 10 weight \% of sulphur (elementary analysis) with free sulphur not exceeding $0.4 \%$ (information from the manufacturer).

\subsection{Positron annihilation measurements}

ACAR (angular correlation of annihilation radiation) and PAL (positron annihilation lifetime) techniques were used in our studies. The two kinds of studies were performed in air at room temperature with only exception for the sample of the synthetic zeolite which was heated in vacuum at $593 \mathrm{~K}$ for $10 \mathrm{~h}$ before the ACAR measurements. They were then performed under the pressure of $10^{-2} \mathrm{~N} / \mathrm{m}^{2}$. Powders of each sample, except of natural sodalite and lazurites that were in form of slabs $(10 \mathrm{~mm} \times 10 \mathrm{~mm} \times 2 \mathrm{~mm})$ cut from greater pieces of minerals, were formed into discs, of diameter equal to $20 \mathrm{~mm}$ and of thickness equal to $3 \mathrm{~mm}$, under the pressure of 3 tons.

ACAR measurements were performed from -29 to $+29 \mathrm{mrad}$ with the use of the LS spectrometer of angular resolution with FWHM equal to $0.8 \mathrm{mrad}$, described in details in [26]. Data were accumulated with the step of $0.5 \mathrm{mrad}$ for the period of $3 \times 10^{3} \mathrm{~s}$ at each point resulting in about $10^{5}$ counts at the peak of each distribution with background intensity reaching $3 \%$ of the peak value. The positrons were produced upon disintegration of ${ }^{22} \mathrm{Na}$ nuclei in the source of $15 \mathrm{mCi}$ activity.

PAL measurements were performed with the use of a conventional fast-slow coincidence system with plastic, cylindrical scintillators NE111 $(20 \mathrm{~mm} \times 20 \mathrm{~mm})$. The positron source, ${ }^{22} \mathrm{Na}$ of activity $15 \mu \mathrm{Ci}$, was deposited between two identical thin Hostaphan foils $\left(0.8 \mathrm{mg} \times \mathrm{cm}^{-2}\right.$ each) and then sandwiched between the samples under investigation. A typical decay curve contained about $10^{6}$ counts and had the peak to background ratio of 2500 .

EPR studies of paramagnetic centres in sodalite, lazurite and ultramarine were carried out on polycrystalline (powdered) samples. The EPR spectra were recorded at $77 \mathrm{~K}$ and $300 \mathrm{~K}$ using spectrometers working in X-band (9.2-9.8 GHz) microwave frequency: SE (Radiopan) and ESP 300E (Bruker). Nuclear magnetometer and EPR standards were used for calculation of $g$-factors and magnetic field calibration. The quantitative EPR (QEPR) technique was applied (20.0 mg samples, constant volume of the samples in quartz tubes, constant microwave power, modulation frequency and amplitude, phase etc.; for the calculation of the free-radical concentration "spin concentration") integration procedure and comparison with free-radical standards (DPPH, TEMPO, 4-hydroxy-TEMPO) were used.

\section{Experimental results}

\subsection{Positron annihilation measurements}

ACAR curves normalized to the same area are presented in Fig. 3. One can notice that the ACAR curves belong to three families: the sodalite family, the ultramarine family and the lazurite family differing distinctly in the height of 

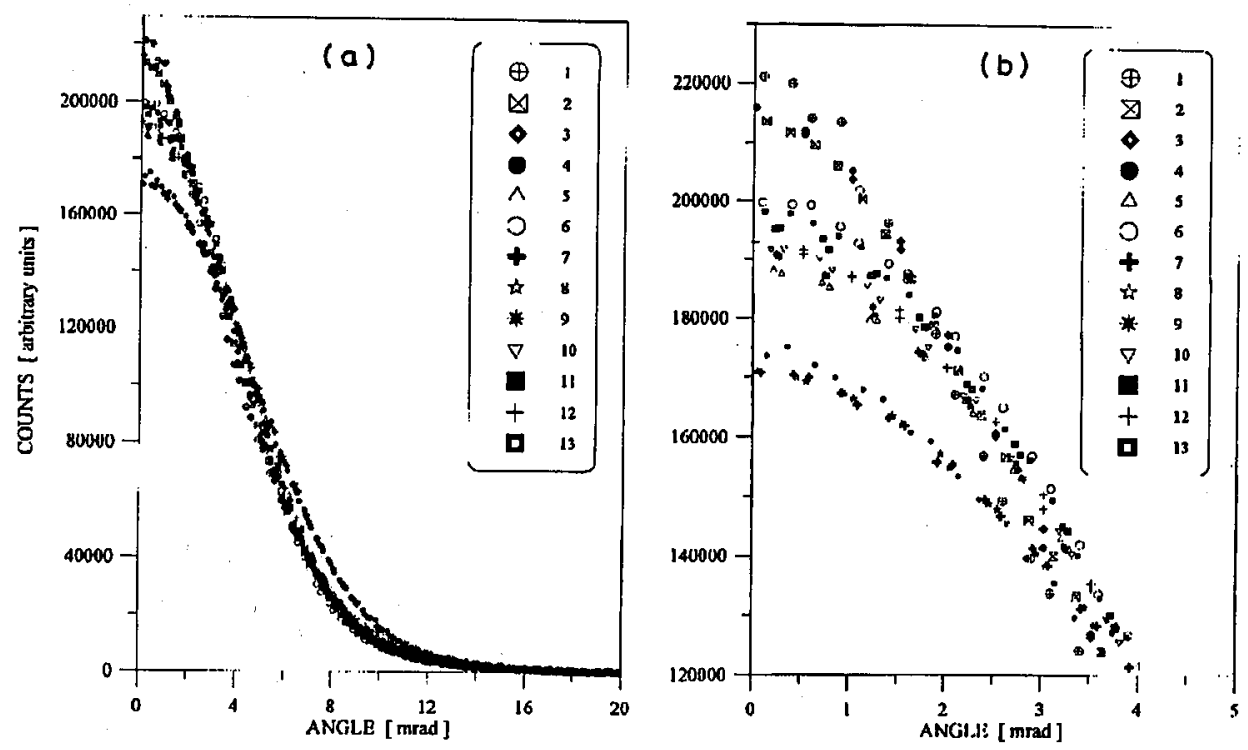

Fig. 3. The set of ACAR curves for all the studied samples (a) and the augmented central parts of the curves (b).

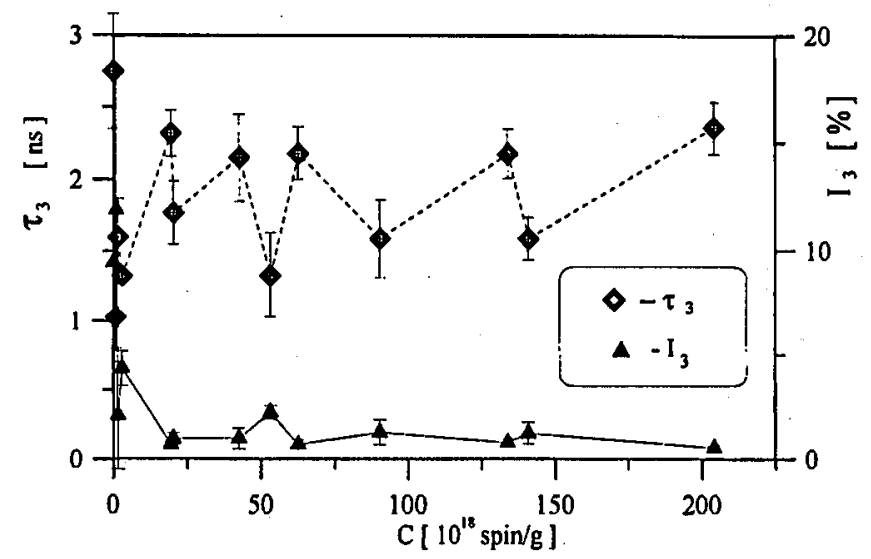

Fig. 4. The long lifetimes $\tau_{3}$ and intensities $I_{3}$ versus concentration $C$ of free radicals. The value of $\tau_{3}$ for the sample No. 1 was taken from [9]. The lines linking consecutive are drawn for eye guide purpose only.

the curve. Only the curves of the sodalite family could be decomposed into three Gaussians with the intensities of the narrowest one corresponding to $15.2 \%, 6.7 \%$ and $9.4 \%$ for samples Nos. 1,2 and 3 .

The PAL spectra were fitted with the sum of three exponentials convoluted with the resolution function of the lifetime spectrometer (a sum of two Gaussians) plus a constant background, using the computer program POSITRONFIT EX- 
TENDED. Although in case of samples Nos. 5, 9, 11, 13 the intensities $I_{3}$ of the longest-lived component were smaller than $1 \%$ the fitting of the PAL spectra for the samples with three components was evidently better than with two ones.

The values of the longest lifetime $\left(\tau_{3}\right)$ observed in PAL spectra and the intensities $\left(I_{3}\right)$ of the component are presented in Fig. 4.

There is a slight tendency of values of $\tau_{3}$ to increase with the concentration of free radicals (Fig. 4) but at the same time the meaningful $I_{3}$ values are seen only for the samples Nos. 1, 2 and 4 having small spin concentration.

\subsection{EPR measurement}

Free radical contents established by us for studied samples are given in Table. Exemplary spectra characteristic of the studied samples are given in Fig. 5.

Sodalites: Free radicals have not been detected in the synthetic sodalite while for the samples of the natural sodalite the concentration of the paramagnetic centres is $10^{18}$ spins/g. The obtained EPR spectrum (Fig. 5, $d$ ) strongly differs from the ones measured for samples of lazurites. The concentration of free radicals is 10-100 times lower for the sodalites in comparison with the lazurites. Moreover, in the lazurites and the ultramarines the dominating signal is characteristic of $\mathrm{S}_{3}^{-}$ $\left(g_{\mathrm{av}}=2.029\right)$ while in case of the sodalites quite different signal at $g=2.012$ is observed. This signal is attributed rather to oxygen containing free radicals; the observed $g$ parameter is very close to $\mathrm{SO}_{4}^{-}$radical in anhydrite $(g=2.011$, $\left.g=2.12, g_{\text {av }}=2.012\right)[27]$.

Lazurites: The anisotropy of the EPR signal of lazurites may be observed even at $300 \mathrm{~K}$ (Fig. 5, $b, c$ for samples Nos. 4 and 8). The parameters: $g_{1}=2.050$, $g_{2}=2.033, g_{3}=2.004\left(g_{\mathrm{av}}=2.029\right)$ are characteristic of the same paramagnetic centre $\mathrm{S}_{3}^{-}$as in case of ultramarines, but in rather ordered $\mathrm{Al}$, Si lattice. The concentration of the EPR centres for the deep-coloured "ordered" lazurites is equal to $5 \times 10^{19}$ spins $/ \mathrm{g}$.

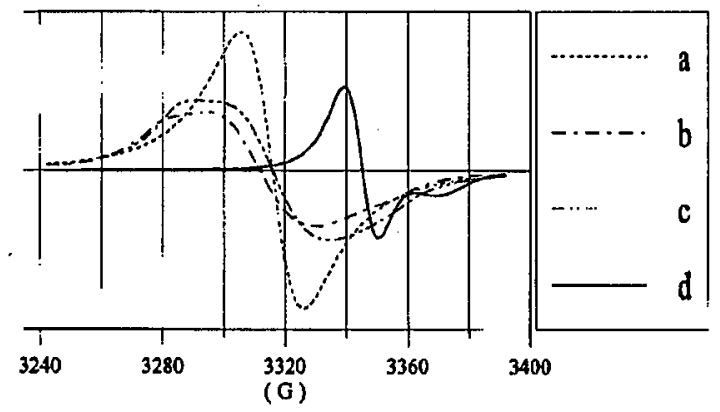

Fig. 5. The EPR lines for: $a-$ ultramarine, $b$ and $c-$ lazurites (samples Nos. 4 and 8$), d-$ natural sodalite. 
Ultramarines: Concentration of paramagnetic centres (mainly $\mathrm{S}_{3}^{-}$) in ultramarines is approximately equal to $2 \times 10^{20}$ centres/g for the deep-blue samples (sample No. 13); for the red, violet, green ultramarines the concentration is lowered to $n \times 10^{19}$ centres/g. The typical EPR spectrum for the blue ultramarine (DTO1) is shown in Fig. 5, $a$. The signal is isotropic at $77 \mathrm{~K}$ and $300 \mathrm{~K}$. The single resonance line centred at $g=2.029$ is characteristic of $\mathrm{S}_{3}^{-}$paramagnetic ions in disordered $\mathrm{Si}, \mathrm{Al}$ lattice (similarly to the structure of glasses). For the green and red ultramarines an anisotropy of the EPR signal may be observed at $77 \mathrm{~K}$.

The paramagnetic centres of investigated samples indicate that the lazurites were formed under reducing conditions, while the sodalites in strongly oxidizing environment. This is confirmed by paragenesis of these minerals [28].

\section{Discussion}

The investigations were undertaken to study positron annihilation in samples with the same type of empty space in their structure. Although the same truncated octahedral sodalite cages are present in all studied samples, their fillers are different. The "empty cage", i.e. not containing atoms at the centre of the cage, occurs only in case of the synthetic sodalite (sample No. 1). In addition to sodium cations (synthetic sodalite) one can find in cages $\mathrm{Cl}^{-}$ions, free radicals $\mathrm{SO}_{4}^{-}$(natural sodalites), $\mathrm{Cl}^{-}, \mathrm{SO}_{4}^{2-}, \mathrm{S}^{2-}$ ions, free radicals $\mathrm{S}_{3}^{-}$(lazurites), free radicals $\mathrm{S}_{3}^{-}$ and $S_{2}^{2-}$ ions (ultramarines) and sometimes water. It seems to us that the influence of negatively charged species present in cages on positron annihilation parameters is dominant. Such species are attractive for positrons and the electron sets offered by each of them for annihilation are different. In case of ACAR curves one can see three families of them, namely the sodalite, the ultramarine and the lazurite family. Comparison of the results of ACAR measurements with the ones of the EPR studies indicates that there is correspondence between them. Similarly to three families of the ACAR curves, different types of EPR lines were obtained for three groups of samples: sodalites, lazurites and ultramarines. It is possible that the annihilation of positrons takes place mainly with unpaired electrons recorded by the EPR technique. To check our supposition one should carry out calculations of the electron density in sodalite cages with different fillers and positron distributions there. Such calculations should show where positron density maxima occur.

It is noticeable that differences between curves measured for mineral samples of the same family (sodalite, lazurite) are smaller than the ones seen in case of different synthetic ultramarines. The greatest difference occurs for ultramarine samples of nearly the same concentration of free radicals (Nos. 5 and 6). ACAR curves for blue ultramarines (samples Nos. 10, 11, 12,13) are also different. In our opinion it reflects the fact that ultramarine is chemically nonhomogeneous; beside proper ultramarine it contains an admixture of other chemical compounds presenting basically the structure of alumino-silicates and resembling the minerals of the sodalite group. The amount of them can be very large, reaching even $30 \%$ of the total content [29]. One should take into account the fact that as it was shown in [23] ultramarines are disordered as far as the Al, Si-site ordering is considered. It is known that the site ordering of the framework atoms has a profound effect on the potential distribution in the sodalite and electronic properties [30]. 
The long lifetimes $\tau_{3}$ present in the lifetime spectra prove the formation of positronium in the studied samples. In general, the value of such long lifetime is used to estimate the mean radius of empty space accommodating the positronium atom. A simple quantum-mechanical model $[31,32]$ based on the assumptions given below is used:

1. o-Ps atom is localised in a spherical free-volume (a hole, a cage, a void) region of radius $R$.

2. o-Ps annihilates via pick-off in a homogeneous electron layer of thickness $\Delta R$ inside the well surrounding the region of the free volume. The o-Ps annihilation rate inside the electron layer is assumed to be equal to $2 \mathrm{~ns}^{-1}$.

3. The sum of $R+\Delta R$ is equal to $R_{0}$, the size of the spherical well of the infinite and square potential.

As a result of the approach given above one obtains the expression (1) for the rate of annihilation of the trapped o-Ps, $\lambda=1 / \tau_{3}$,

$$
\lambda=2\left\{1-R /(R+\Delta R)+(2 \pi)^{-1} \sin [2 \pi R /(R+\Delta R)]\right\} .
$$

$\Delta R$ is an empirical parameter obtained by fitting the measured o-Ps annihilation rates in materials of well defined empty spaces [33] and is usually accepted to be equal to $16.6 \mathrm{~nm}$.

In case of the studied samples the $\tau_{3}$ values for samples Nos. $1,5,7,9,11$ and 13 are close to $2.5 \mathrm{~ns}$, the value corresponding to $R=0.66 \mathrm{~nm}$, the free diameter of the sodalite cage. Among the samples mentioned above there is only one mineral sample (No. 7). Similar lifetimes had occurred in the lifetime spectra measured by us for synthetic zeolites $4 \mathrm{~A}$ and $5 \mathrm{~A}[8]$ while such values as the obtained by us for samples Nos. $3,4,6,8,10,12\left(\tau_{3} \approx 1.5 \mathrm{~ns}\right)$ occurred previously for the synthetic zeolite $3 \mathrm{~A}[8,10$ (paper by Ito et al.)]. In the framework of zeolites $3 \mathrm{~A}, 4 \mathrm{~A}$ and $5 \mathrm{~A}$ sodalite cages are present (the so-called $\beta$ cages) besides 26 -hedra of type I. At present it is not sure if the measured values of $\tau_{3}$ reflect the size pores of particular kind or they are the ones averaged over several different holes (including defects of the structure of the framework of the studied samples). However one should take into account that in case of our studies the meaningful values of $I_{3}$ were detected only in case of samples Nos. 1, 2 and 4. For others no serious conclusions about free volume can be drawn.

The rapid decrease in the intensities $I_{3}$ following the increase in free radical concentration and seen in Fig. 4 for samples of lazurites and ultramarines can be explained both by the increase in concentration of free radicals as well as by the bigger size of the free radicals $\mathrm{S}_{3}^{-}$in comparison with the $\mathrm{SO}_{4}^{-}$. It is known [34] that they have the $\mathrm{C}_{2 v} \mathrm{~S}-\mathrm{S}-\mathrm{S}$ configuration with S-S distances between 0.20 and $0.21 \mathrm{~nm}$, an S-S-S angle of about $110^{\circ}$ and are of course bigger species than the $\mathrm{SO}_{4}^{-}$ones. The additional group $\mathrm{SO}_{4}^{2-}$ present in some cages of lazurites (the ionic radius of $0.244 \mathrm{~nm}$ [35]) is also bigger than the $\mathrm{Cl}^{-}$ions present in natural sodalites (the ionic radius of $0.167 \mathrm{~nm}$ [35]). According to Ito [37] low values of $I_{3}(1-3 \%)$ can quite probably be due to o-Ps in the intercrystallite regions.

In case of the studied ultramarines the number of cages with the big $\mathrm{S}_{3}^{-}$ free radicals increases 10 times from sample No. 5 to sample No. 13 while the 

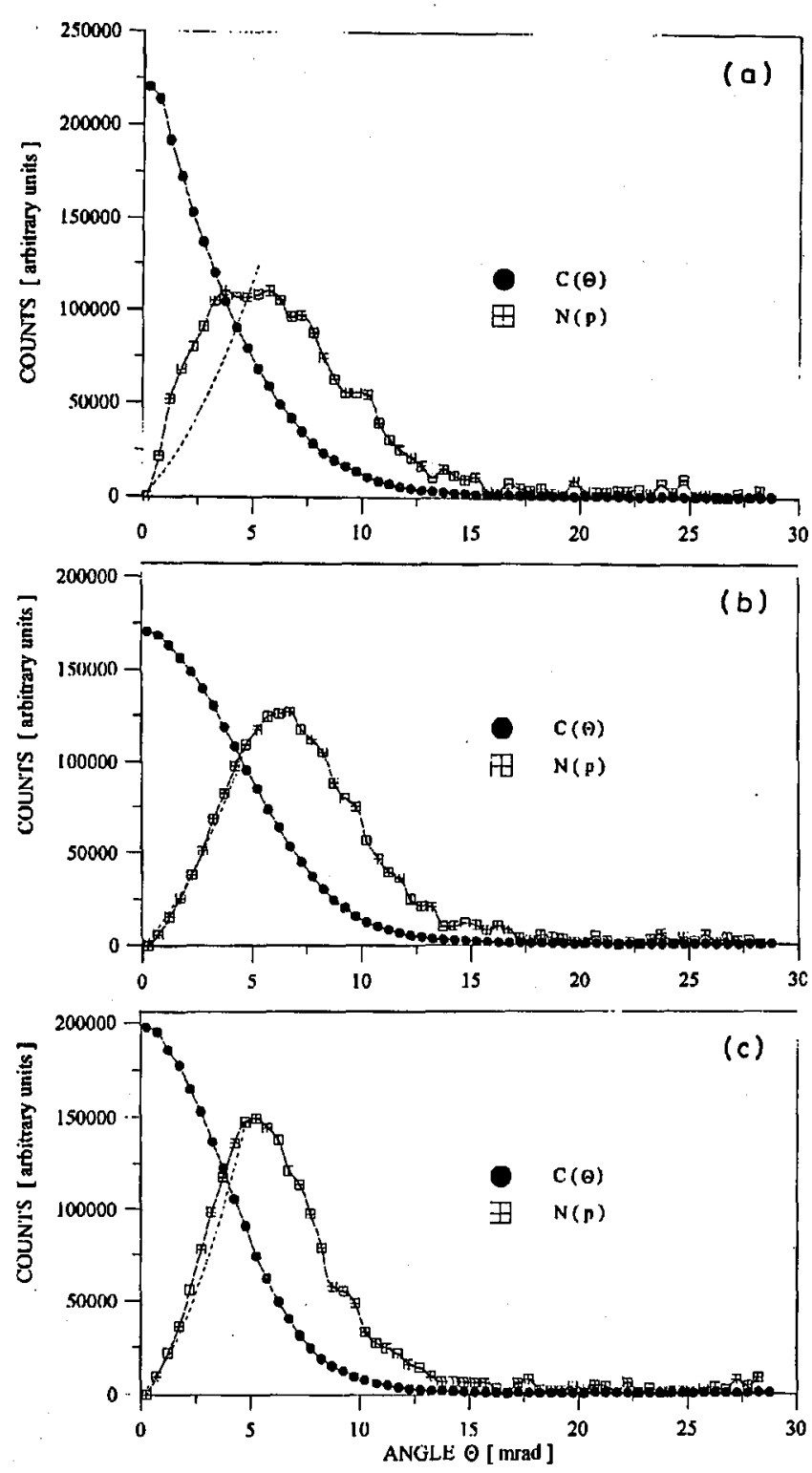

Fig. 6. The ACAR curves $C(\Theta)$ and the momentum distributions $N(p)$ for samples No. 1 (a), No. 8 (b) and No. 11 (c). The momentum distributions were obtained with the use of Stewart's method [36]. The dashed curve in $N(p)$ represents the parabola $N(p)=$ const $\cdot p^{2}$, fitted to the value of $p=0.0045 \mathrm{mc}$.

total amount of sulphur does not change so much in them. The role of the free radicals present in the studied samples is undoubted although it cannot be precisely determined as blurred by the presence of other species in cages of the samples. 
It seems to us that the inhibition of positronium formation by free radicals takes place in the studied samples. The decreases in the intensity of the narrow component in the ACAR curves (reflected also in Fig. 6 in momentum distributions of electrons participating in $2 \gamma$ annihilation) as well as in the intensity of the longest-lived component, prove it. One should take into account also the second effect, namely the filling of cages by different species, mentioned above. If there is no open space which can accommodate o-Ps the long-lived component does not appear.

In case of such inhibition, as well as in case of flling cages, studies of empty space (pores, holes etc.) are seriously limited.

\section{Acknowledgment}

We thank. Prof. Y. Ito, Dr. A. Stelmaszczyk and Prof. A.B. Więckowski for the samples. The financial support from the State Committee for Scientific Research (Republic of Poland), grant No. 604589101 and No. GBW/94/5/IFD, is acknowledged.

\section{References}

[1] M. Sachanbiński, M. Szuszkiewicz, S. Szuszkiewicz, in: Collected Abstracts of Inter. Mineralogical Assoc. 12th General Meeting, Eds. A. Baronnet, Y. Calas, La Societé Française de Mineralogie et de Cristallographie, Orleans 1980, p. 71.

[2] B. Geffroy, I. Diallo, R. Paulin, Bull. Mineral. 107, 795 (1984).

[3] H. Graetsch, O.W. Florke, G. Mieche, Phys. Chem. Minerals 14, 249 (1987).

[4] J. Chojcan, M. Sachanbiński, Acta Phys. Pol. A 83, 267 (1993).

[5] J. Chojcan, M. Sachanbinski, in: Proc. XXVIII Zakopane School of Physics on Condensed Matter Studies by Nuclear Methods, Eds. A. Görlich, K. Tomala, Jagiellonian Univ. \& Inst. of Nucl. Phys., Cracow 1993, p. 296.

[6] F.II. Hsu, E.R. Vance, Phys. Chem. Minerals 6, 47 (1980).

[7] G.M. Bartenev, A.D. Cyganov, A.Z. Varisov, Izv. Vyssh. Uchebn. Zaved. Fiz. 5, 59 (1971).

[8] M. Dębowska, J.Ch. Abbe, G. Duplaitre, Phys. Slatus Solidi B 146, 91 (1988).

[9] Y. Ito, T. Takano, M. Hasegawa, Appl. Phys. A 45, 193 (1988).

[10] M.B. Perkal, W.B. Walters, J. Chem. Phys. 53, 190 (1970); Y. Ito, T. Takano, H. Kojima, S. Matsuoka, H. Nakamura, T. Tamura, in: Positron Annihilation, Proc. 6th ICPA, The University of Texas at Arlington, 1982, Eds. P.G. Coleman, S.C. Sharma, L.M. Diana, North-Holland, New York 1982, p. 671.

[11] A. Baranowski, M. Dębowska, K. Jerie, W. Świątkowski, Acta Univ. Wratislav. Mat. Fiz. Astron. XLVIII, 113 (1986).

[12] M. Dębowska, A. Baranowski, K. Jerie, W. Świątkowski, Phys. Status. Solidi A 97, K35 (1986); J.Ch. Abbe, M. Dębowska, Cryst. Res. Technol. 23, 291 (1988).

[13] W. Low, Adv. Electron. Electron Phys. 24, 51 (1968).

[14] A.S. Marfunin, Spektroskopiya, luminescenciya i radiacyonnye centry $w$ mineralakh, Niedra, Moskva 1975. 
[15] C.P. Poole, H.A. Farach, T.P. Bishop, Magn. Res. Rei. 4, 137 (1977).

[16] C.P. Poole, H.A. Farach, T.P. Bishop, Magn. Res. Rev. 4, 225 (1978).

[17] A. Jezierski, M. Sachanbiński, Acta Univ. Wratislav. Pr. Geol.-Mineral. XXIII, 199 (1991).

[18] R.M. Barrer, J.F. Cole, J. Chem. Soc. (A), 1516 (1970).

[19] S.P. Żdanov, N.N. Buntar, E.N. Jegorova, Dokl. Akad. Nauk SSSR 154, 419 (1964).

[20] References [1], [4], [11] in S.E. Tarling, P. Barnes, A.L. Mackay, J. Appl. Cryst. 17, 96 (1984).

[21] References [5], [6], [10] in S.E. Tarling, P. Barnes, A.L. Mackay, J. Appl. Cryst. 17, 96 (1984).

[22] A.B. Więckowski, in: Proc. Conf. on Radio- and Microwave Spectroscopy RAMIS-79, Poznań 1979, Ed. N. Piślewski, 1st ed., PAN, Poznań 1979, p. 265.

[23] P. Barnes, Nondestr. Test. Eval. 5, 319 (1990).

[24] F.M. Jaeger, Trans. Faraday Soc. 25, 320 (1929).

[25] F. Seel, II.J. Guttler, A.B. Więckowski, B. Woll, Z. Nat.forsch. B 84, 1671 (1979).

[26] B. Rozenfeld, A. Baranowski, K. Jerie, Nukleonika 19, 817 (1974).

[27] R. Iluzimura, Jpn. J. Appl. Phys. 18, 2031 (1979).

[28] W.G. Ivanov, A.N. Sapożnikov, in: Lazurity SSSR, Nauka, Novosibirsk 1985, p. 89.

[29] A. Więckowski, Phys. Stalus Solidi 42, 125 (1970).

[30] G.D. Stucky, V.I. Srdanov, W.T.A. Harrison, T.E. Gier, N.L. Keder, K.L. Moran, K. Haug, H.I. Metiu, Supramolecular Archilecture. Synthetic Control in Thin Films and Solids, ACS Symposium Series 499, Ed. T. Bein, American Chemical Society, Washington, DC 1992.

[31] S.J. Tao, J. Chem. Phys. 56, 5499 (1972).

[32] M. Eldrup, D. Lightbody, J.N. Sherwood, Chem. Phys. 63, 51 (1981).

[33] H. Nakanishi, S.J. Wang, Y.C. Jean, in: Positron Annihilation Studies of Fluids, Ed. S.C. Sharma, World Scientific, Singapore 1988, p. 292.

[34] S.E. Tarling, P. Barnes, J. Klinowski, Acta Crystallogr. B 44, 128 (1988).

[35] J.E. Huheey, Inorganic Chemistry, 3 ed., Harper \& Row, New York 1983.

[36] A.T. Stewart, Can. J. Phys. 35, 168 (1957).

[37] Y. Ito, private communication. 